\title{
Effects of aerobic and resistance exercise in murine models of rheumatoid arthritis and osteoarthritis - a systematic review
}

\author{
Thaís Caroline Schnaufer ${ }^{1, A-D, F \oplus}{ }^{1, A}$ Marcela Aparecida Leite ${ }^{1, A-D, F \oplus}{ }^{\oplus}$, Camila Amaral Coracini ${ }^{1, A, C, E-F \oplus}$, \\ Patrícia Oehlmeyer Nassar ${ }^{1, A, C, E-F \oplus}$, Alberito Rodrigo de Carvalho ${ }^{1, A, C, E-F} \oplus$, \\ Gladson Ricardo Flor Bertolini ${ }^{1, A, C, E-F \oplus}$ \\ 1 Universidade Estadual do Oeste do Paraná, Brazil \\ A - Research concept and design, B - Collection and/or assembly of data, C - Data analysis and interpretation, \\ $D$ - Writing the article, E-Critical revision of the article, F- Final approval of the article
}

\begin{abstract}
Thaís Caroline Schnaufer, Marcela Aparecida Leite, Camila Amaral Coracini, Patrícia Oehlmeyer Nassar, Alberito Rodrigo de Carvalho, Gladson Ricardo Flor Bertolini. Effects of aerobic and resistance exercise in murine models of rheumatoid arthritis and osteoarthritis: a systematic review. J Pre-Clin Clin Res. 2022; 16(1): 16-20. doi: 10.26444/jpccr/145974
\end{abstract}

\begin{abstract}
I Abstract
Introduction and Objective. Rheumatoid arthritis (RA) is an inflammatory and systemic autoimmune disease that affects peripheral joints leading to joint degradation, pain, deformities, decreased activities of daily living, and sedentary lifestyle, resulting in secondary sarcopenia. Osteoarthritis (OA), in turn, is a multifactorial disease associated with joint degeneration and impairment of the musculoskeletal system as a whole, affecting joint movement and stability. In both pathologies, there is loss of muscle mass and functional impairment, and physical exercise is a therapeutic alternative to minimize these consequences. The aim of the review is to demonstrate the effects of different physical exercise modalities on muscle mass loss in murine models of $\mathrm{OA}$ and RA.

Materials and method. The databases used were PUBMED, EMBASE, Cochrane Database, LILACS, and Google Scholar. The review included studies which induced experimental models of OA or RA in rats or mice; used any exercise modality as an intervention; and analyzed some quantitative muscle histomorphometric measurs. The search strategy included all keywords on the topic identified in previous research and adapted for each database. Studies published in any language and in any year were included. An analysis of the studies was performed by two independent reviewers and data were extracted from the articles using tools developed by the reviewers.

Results. After completing the definitive search in the databases, 193 studies were found, of which only 2 were included in this review, one addressing the effects of resistance exercise in rats with RA, and another using aerobic exercise to treat rats with $\mathrm{OA}$.

Conclusion. Treatment with different forms of physical exercise contributed to attenuation of muscle mass loss in animal models of OA and RA.
\end{abstract}

\section{Key words}

exercise therapy, animals models, inflammation, joints

\section{INTRODUCTION}

Rheumatoid arthritis (RA) is an autoimmune disease that causes inflammation and joint degradation, characterized by symmetric and chronic synovitis that mainly affects the peripheral joints. In addition to joint inflammation, RA most frequently triggers systemic inflammation that can lead to pain, with consequent decreased activities of daily living, sedentary lifestyle, and even joint deformities $[1,2]$. This systemic inflammation can also lead to secondary sarcopenia, which appears to be primarily driven by catabolic processes. When systemic inflammation persists and is associated with anorexia, asthenia, and/or physical inactivity, additional muscle loss pathways are activated, altering the balance of muscle tissue remodelling, and may activate different intracellular proteolysis pathways [3-5].

Osteoarthritis (OA), in turn, is a multifactorial disease that affects the musculoskeletal system as a whole, especially

Address for correspondence: Gladson Ricardo Flor Bertolini, Universidade Estadual do Oeste do Paraná, Rua Universitária, 2069., 85819110, Cascavel, Brazil

E-mail: gladsonricardo@gmail.com

Received: 15.10.2021; accepted: 20.01.22; first published: 03.02.2022 joint tissues (causing degeneration in meniscus, ligament, and synovium) and muscle tissues (leading to loss of periarticular muscle mass) [6]. Because the muscular system performs, among others, the functions of joint stability and strengthening [7], once compromised in OA, there is generalized fatigue, functional disability, increased risk of falls, as well as pain and stiffness, directly affecting the quality of life of sufferers [8].

Aimed at minimize the consequences of RA and OA, physical exercise has been used as a non-pharmacological treatment possibility, mainly because it is accessible and low-cost [9-11], and promotes benefits such as improved cardiorespiratory fitness and increased muscle mass, aerobic capacity, joint mobility, and physical function [12]. Overall, exercise promotes adaptive responses in skeletal muscle as a result of the cumulative effect of activating a series of molecular signalling pathways which, in turn, modulate protein synthesis and degradation to promote muscle hypertrophy while preventing atrophy [13].

Resistance exercise, which aims to provide resistance against muscle action through weights, is an important form of treatment for sarcopenia because it generates an increase 
in the amount of type I muscle fibres and the cross-sectional area of type II fibres [14], promoting regulation of the rate of protein synthesis [15], and decreasing the levels of atrogin-1, MuRF-1, and myostatin; therefore, acting on the prevention of muscle atrophy [13]. Aerobic exercise, on the other hand, another modality of exercise which consists of long-duration, low-intensity resistance exercises [16], acts by improving pain, oedema, and joint function, which is limited in $\mathrm{OA}$ and RA $[17,18]$.

However, although the benefits of physical exercise for the treatment of RA and OA and muscle atrophy are known, the studies are divergent as to the types of exercises and protocols used. Therefore, a systematic review compiling all this information is justified with the aim of future clinical direction. In view of this, the objective of the present study was to highlight the effects of different modalities and physical exercise protocols on muscle mass loss in murine models of OA and RA.

\section{MATERIALS AND METHOD}

Prior to conducting this review, a preliminary search in PROSPERO and PUBMED was conducted until 15 June 2021, aimed at finding other protocols/reviews with the same objective, and to rule out the possibility of duplication of studies.

Search strategy. This systematic review included studies published in any language and year in the following databases: PUBMED, EMBASE, Cochrane Database and LILACS, as well as Google Scholar as grey literature. The final search strategy was outlined in PUBMED and encompassed all keywords found in articles on the topic in the preliminary search. These were later adapted for each database (Appendix 1).

Inclusion and exclusion criteria. To be included in the review, the studies should adhere the following criteria: 1) use rats or mice of any gender, age or lineage, as samples induced to some experimental model of OA or RA; 2) use any modality of physical exercise as an intervention; 3 ) have analyzed at least one quantitative measure regarding muscle histomorphometry.

Articles were excluded if they involved the following: 1) the samples used were not rats or mice; 2) the sample was not submitted to some model of OA or RA, or had other associated pathology; 3) if there were groups that only performed exercise combined with another form of therapy; 4) did not analyze some muscle histomorphometric parameter; 5) did not detail the parameters used in the exercise; 6) cohort studies, literature reviews, dissertations, theses, editorials, and conference panels; and 7) duplicate studies or were unavailable in full.

Article Selection. After the final search of the strategies in all databases, the retrieved citations were evaluated and duplicate studies excluded. Subsequently, two independent reviewers read the titles and abstracts to verify that they met the preestablished eligibility criteria. The studies initially included were read in full and again evaluated. Disagreements that arose between the reviewers were resolved by discussion, or by a third reviewer when necessary.
Data extraction, analysis and presentation. After the end of the selection phase, the data was extracted from the articles using tools developed by the reviewers, in an excel table, in which the data included specific information such as author, year of publication, country, pathology induced, site of inflammation, muscle analyzed, intervention, comparisons, and outcomes. The data were modified and revised as needed during extraction and analysis, and disagreements that arose were resolved through discussion or by an additional reviewer when necessary.

\section{RESULTS}

After the final search of the databases, a total of 193 studies were found, of which 32 articles were excluded because they were duplicates, 156 were excluded after reading the title and abstract, and 5 studies were read in full. After analyzing the eligibility criteria, only 2 articles were included in the present systematic review (Fig. 1).

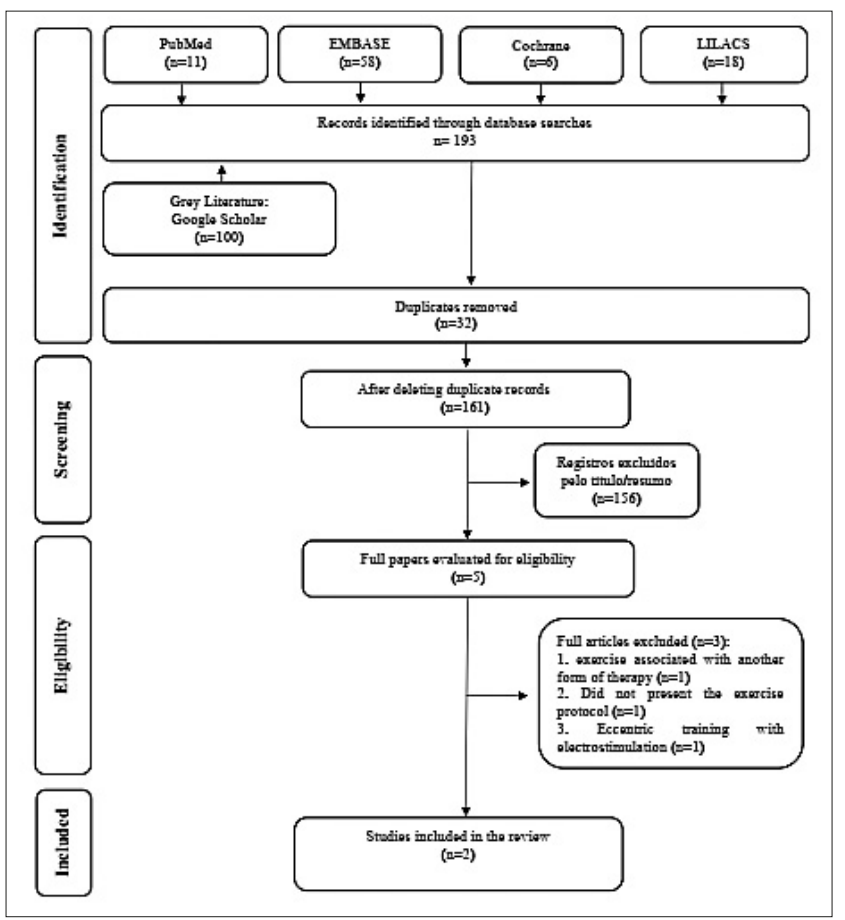

Figure 1. Flow diagram of the literature search and the selection criteria

Of the articles included, one was a RA model [19] and the other an OA model [20] - both written and published in English. In the article by Oliveira et al. [19], the resistance exercise (stair climbing with load) was used in a model of RA, and in the study by Assis et al. [20], aerobic exercise (running) associated or not with low-power LASER therapy, was used in a model of (Tab. 1).

\section{DISCUSSION}

The results obtained demonstrate that RA and OA cause morphological alterations in the muscle and in the expression of enzymes of the ubiquitin-proteosome system, consistent with muscle atrophy. Resistance and aerobic exercises provided regulation of myostatin, atrogin-1, MyoD, MuRF- 
Table 1. Summary of included studies

\begin{tabular}{|c|c|c|c|c|c|c|c|c|}
\hline \multirow{2}{*}{$\begin{array}{l}\text { Author } \\
\text { / Year }\end{array}$} & \multirow[t]{2}{*}{ Country } & \multirow[t]{2}{*}{ Pathology } & \multicolumn{5}{|c|}{ Methods } & \multirow[t]{2}{*}{ Results } \\
\hline & & & Sample & $\begin{array}{c}\text { Affected } \\
\text { joint / muscle } \\
\text { analyzed }\end{array}$ & Intervention & Comparison & Outcome & \\
\hline $\begin{array}{l}\text { Oliveira } \\
\text { et al., } \\
2018\end{array}$ & Brazil & $\begin{array}{c}\text { RA } \\
\text { (Induced by } \\
\text { methylated } \\
\text { bovine } \\
\text { albumin + } \\
\text { CFA + } \\
\text { Mycobacterium } \\
\text { tuberculosis) }\end{array}$ & $\begin{array}{c}26 \text { Wistar } \\
\text { rats } \\
( \pm 126 \mathrm{~g} \\
8 \text { weeks } \\
\text { old })\end{array}$ & $\begin{array}{c}\text { Tibiotarsal } \\
\text { joint } \\
\text { Gastrocnemius }\end{array}$ & $\begin{array}{l}\text { Resistance exercise: } \\
\text { - Stair climbing ( } 1.1 \times \\
0.18 \mathrm{~cm}, 2 \mathrm{~cm} \text { between } \\
\text { steps, } 80^{\circ} \text { incline) with } \\
\text { load. Training }=5 \text { sets of } \\
3 \text { repetitions, with } 120 \mathrm{~s} \\
\text { interval between them, } \\
\text { and progressive load of } \\
0 \%, 25 \%, 50 \%, 75 \% \text {, and } \\
100 \% \text { of body weight. } \\
\text { If the animal failed, the } \\
\text { load was reduced by } 25 \% \text {. } \\
\text { Training was performed } \\
\text { once, } 6 \text { hrs before } \\
\text { euthanasia. }\end{array}$ & $\begin{array}{l}\text { - Control Group (CG): no } \\
\text { intervention, } \mathrm{n}=7 \\
\text { - Exercise group (EG), } \\
\mathrm{n}=6 \\
\text { - Rheumatoid arthritis } \\
\text { group (GAR), } \mathrm{n}=6 \\
\text { - Rheumatoid arthritis } \\
\text { + exercise group } \\
\text { (GAR+EX), } \mathrm{n}=7\end{array}$ & $\begin{array}{l}\text { 1) Weight of } \\
\text { gastrocnemius } \\
\text { muscle } \\
\text { 2) Cross- } \\
\text { sectional area of } \\
\text { gastrocnemius } \\
\text { muscle } \\
\text { 3) Expression } \\
\text { of myostatin } \\
\text { and atrogin-1 } \\
\text { proteins } \\
\text { 4) Expression of } \\
\text { MuRF-1 enzyme }\end{array}$ & $\begin{array}{l}\text { 1) Smaller in the GAR } \\
\text { and GAR+EX groups vs. } \\
C G \text { and } E G \text { ( } p<0.05 \text { ) } \\
\text { 2) Decreased in GAR } \\
\text { and GAR+EX groups vs. } \\
\text { CG and EG ( } p<0.05 \text { ) } \\
\text { 3) Increased in GAR } \\
\text { group vs. GC, EG and } \\
\text { GAR+EX; and NSD in } \\
\text { GAR+EX group ( } p<0.05 \text { ) } \\
\text { 4) All groups = NSD } \\
\text { ( } p>0.05 \text { ) }\end{array}$ \\
\hline $\begin{array}{l}\text { Assis } \\
\text { et al., } \\
2015\end{array}$ & Brazil & $\begin{array}{l}\text { OA } \\
\text { (Induced by } \\
\text { sectioning } \\
\text { the anterior } \\
\text { cruciate } \\
\text { ligament) }\end{array}$ & $\begin{array}{c}50 \text { Wistar } \\
\text { rats } \\
( \pm 150 \mathrm{~g} \\
6 \text { weeks } \\
\text { old })\end{array}$ & $\begin{array}{l}\text { Femorotibial } \\
\text { joint } \\
\text { Quadriceps }\end{array}$ & $\begin{array}{l}\text { Aerobic exercise: } \\
\text { - Running, } 16 \mathrm{~m} / \mathrm{min}, 3 \times / \\
\text { week, } 50 \mathrm{~min} / \text { day, for } 8 \\
\text { weeks. } \\
\quad \text { Laser: } \\
\text { - GaAlAs diode laser, } \\
\text { continuous mode, } 808 \mathrm{~nm} \text {, } \\
50 \mathrm{~mW}, 28 \mathrm{sec} \text { irradiation, } \\
50 \mathrm{~J} / \mathrm{cm}^{2} \text {, irradiance } 1.7 \mathrm{~W} / \\
\mathrm{cm}^{2} \text {, total energy } 1.4 \mathrm{~J} \text { per } \\
\text { spot per section, } 3 \times / \text { week, } \\
\text { for } 8 \text { weeks. }\end{array}$ & $\begin{array}{l}\text { - Control Group (CG): no } \\
\text { intervention, } \mathrm{n}=10 \\
\text { - Osteoarthritis group } \\
\text { without treatment } \\
\text { (OAC), } \mathrm{n}=10 \\
\text { - Osteoarthritis with } \\
\text { Exercise Group (OAT), } \\
\mathrm{n}=10 \\
\text { - Osteoarthritis with } \\
\text { Laser (OAL) Group, } \\
\mathrm{n}=10 \\
\text { - Group Osteoarthritis } \\
\text { Exercise + Laser } \\
\text { (OATL), } \mathrm{n}=10\end{array}$ & $\begin{array}{l}\text { 1) Cross- } \\
\text { sectional area } \\
\text { of quadriceps } \\
\text { muscle } \\
\text { 2) Quadriceps } \\
\text { muscle fibre } \\
\text { density } \\
\text { 3) Expression of } \\
\text { MuRF-1 enzyme } \\
\text { and atrogin-1 } \\
\text { protein }\end{array}$ & $\begin{array}{l}\text { 1) Reduction in all } \\
\text { groups vs. } C G \text { ( } p<0.001 \text { ); } \\
\text { and increase in groups } \\
\text { OAT and OATL vs. OAC } \\
\text { ( } p<0.001 \text { ) } \\
\text { 2) Increase in OAC, OAL, } \\
\text { OAT, and OATL groups } \\
\text { vs. CG ( } p<0.003 \text { ); and } \\
\text { decrease in OAT and } \\
\text { OATL groups vs. OAC } \\
\text { ( }<<0.02 \text { ) } \\
3 \text { ) Increase in OAC vs. } \\
\text { OAL ( } p<0.05 \text { ); all other } \\
\text { groups = NSD ( }>0.05 \text { ) }\end{array}$ \\
\hline
\end{tabular}

Table 1. Summary of included studies

\begin{tabular}{|c|c|c|c|c|c|c|c|c|}
\hline \multirow{2}{*}{$\begin{array}{l}\text { Author } \\
\text { / Year }\end{array}$} & \multirow[t]{2}{*}{ Country } & \multirow[t]{2}{*}{ Pathology } & \multicolumn{5}{|c|}{ Methods } & \multirow[t]{2}{*}{ Results } \\
\hline & & & Sample & $\begin{array}{c}\text { Affected } \\
\text { joint / muscle } \\
\text { analyzed }\end{array}$ & Intervention & Comparison & Outcome & \\
\hline $\begin{array}{l}\text { Oliveira } \\
\text { et al., } \\
2018\end{array}$ & Brazil & $\begin{array}{c}\text { RA } \\
\text { (Induced by } \\
\text { methylated } \\
\text { bovine } \\
\text { albumin + } \\
\text { CFA + } \\
\text { Mycobacterium } \\
\text { tuberculosis) }\end{array}$ & $\begin{array}{c}26 \text { Wistar } \\
\text { rats } \\
( \pm 126 \mathrm{~g} \\
8 \text { weeks } \\
\text { old })\end{array}$ & $\begin{array}{c}\text { Tibiotarsal } \\
\text { joint } \\
\text { Gastrocnemius }\end{array}$ & $\begin{array}{l}\text { Resistance exercise: } \\
\text { - Stair climbing ( } 1.1 \mathrm{x} \\
0.18 \mathrm{~cm}, 2 \mathrm{~cm} \text { between } \\
\text { steps, } 80^{\circ} \text { incline) with } \\
\text { load. Training }=5 \text { sets of } \\
3 \text { repetitions, with } 120 \mathrm{~s} \\
\text { interval between them, } \\
\text { and progressive load of } \\
0 \%, 25 \%, 50 \%, 75 \% \text {, and } \\
100 \% \text { of body weight. } \\
\text { If the animal failed, the } \\
\text { load was reduced by } 25 \% \text {. } \\
\text { Training was performed } \\
\text { once, } 6 \text { hrs before } \\
\text { euthanasia. }\end{array}$ & $\begin{array}{l}\text { - Control Group (CG): no } \\
\text { intervention, } n=7 \\
\text { - Exercise group (EG), } \\
\text { n=6 } \\
\text { - Rheumatoid arthritis } \\
\text { group (GAR), } n=6 \\
\text { - Rheumatoid arthritis } \\
\text { + exercise group } \\
\text { (GAR+EX), } n=7\end{array}$ & $\begin{array}{l}\text { 1) Weight of } \\
\text { gastrocnemius } \\
\text { muscle } \\
\text { 2) Cross- } \\
\text { sectional area of } \\
\text { gastrocnemius } \\
\text { muscle } \\
\text { 3) Expression } \\
\text { of myostatin } \\
\text { and atrogin-1 } \\
\text { proteins } \\
\text { 4) Expression of } \\
\text { MuRF-1 enzyme }\end{array}$ & $\begin{array}{l}\text { 1) Smaller in the GAR } \\
\text { and GAR+EX groups vs. } \\
\text { CG and EG } \\
\text { 2) Decreased in GAR } \\
\text { and GAR+EX groups vs. } \\
\text { CG and EG } \\
\text { 3) Increased in GAR } \\
\text { group vs. GC, EG and } \\
\text { GAR+EX; and NSD in } \\
\text { GAR+EX group } \\
\text { 4) All groups = NSD }\end{array}$ \\
\hline $\begin{array}{l}\text { Assis } \\
\text { et al., } \\
2015\end{array}$ & Brazil & $\begin{array}{l}\text { OA } \\
\text { (Induced by } \\
\text { sectioning } \\
\text { the anterior } \\
\text { cruciate } \\
\text { ligament) }\end{array}$ & $\begin{array}{c}50 \text { Wistar } \\
\text { rats } \\
( \pm 150 \mathrm{~g} \\
6 \text { weeks } \\
\text { old })\end{array}$ & $\begin{array}{c}\text { Femorotibial } \\
\text { joint } \\
\text { Quadriceps }\end{array}$ & $\begin{array}{l}\text { Aerobic exercise: } \\
\text { - Running, } 16 \mathrm{~m} / \mathrm{min}, 3 \mathrm{x} / \\
\text { week, } 50 \mathrm{~min} / \text { day, for } 8 \\
\text { weeks. } \\
\text { Laser: } \\
\text { - GaAlAs diode laser, } \\
\text { continuous mode, } 808 \mathrm{~nm} \text {, } \\
50 \mathrm{~mW}, 28 \mathrm{sec} \text { irradiation, } \\
50 \mathrm{~J} / \mathrm{cm}^{2} \text {, irradiance } 1.7 \mathrm{~W} / \\
\mathrm{cm}^{2} \text {, total energy } 1.4 \mathrm{~J} \text { per } \\
\text { spot per section, } 3 \times / \text { week, } \\
\text { for } 8 \text { weeks. }\end{array}$ & $\begin{array}{l}\text { - Control Group (CG): no } \\
\text { intervention, } \mathrm{n}=10 \\
\text { - Osteoarthritis group } \\
\text { without treatment } \\
\text { (OAC), } \mathrm{n}=10 \\
\text { - Osteoarthritis with } \\
\text { Exercise Group (OAT), } \\
\mathrm{n}=10 \\
\text { - Osteoarthritis with } \\
\text { Laser (OAL) Group, } \\
\mathrm{n}=10 \\
\text { - Group Osteoarthritis } \\
\text { Exercise + Laser } \\
\text { (OATL), } \mathrm{n}=10\end{array}$ & $\begin{array}{l}\text { 1) Cross- } \\
\text { sectional area } \\
\text { of quadriceps } \\
\text { muscle } \\
\text { 2) Quadriceps } \\
\text { muscle fibre } \\
\text { density } \\
\text { 3) Expression of } \\
\text { MuRF-1 enzyme } \\
\text { and atrogin-1 } \\
\text { protein }\end{array}$ & $\begin{array}{l}\text { 1) Reduction in all } \\
\text { groups vs. CG; and } \\
\text { increase in groups } \\
\text { OAT and OATL vs. OAC } \\
\text { 2) Increase in OAC, OAL, } \\
\text { OAT, and OATL groups } \\
\text { vs. CG; and decrease in } \\
\text { OAT and OATL groups } \\
\text { versus OAC } \\
\text { 3) Increase in OAC } \\
\text { versus OAL; all other } \\
\text { groups = NSD }\end{array}$ \\
\hline
\end{tabular}


1 , and myogenin expression and prevented a decrease in the cross-sectional area of muscle fibres, thus preventing muscle atrophy in animal models of RA and OA.

In a study carried out in elderly people with rheumatoid arthritis, submitted to resistance and endurance exercise protocols, improvements in aerobic capacity, endurance and muscle strength were verified [21]. However, in individuals with knee osteoarthritis, submitted to resistance training, a reduction in pain was observed, including in the walking function [22]; however, these records point to gaps that still need to be filled in the literature regarding the forms of physical exercise, as well as the most suitable modality.

In both RA and OA, a large number of pro-inflammatory cytokines are produced, including TNF- $\alpha$ and IL-6 [23-25]. In the study by Adams et al. [26] it was observed that TNF- $\alpha$ induced MuRF-1 expression in skeletal muscle, leading to a reduction in muscle contractile strength by reducing myofibrillar sensitivity to calcium, which is an important factor in muscle weakness. Therefore, this is believed to be one of the reasons why skeletal muscle in individuals with RA exhibits impaired adaptation to exercise and injury repair [27]. Using an aerobic exercise protocol in mice with high levels of TNF- $\alpha$, Mangner et al. [28] investigated whether exercise could reduce the loss of muscle mass in the diaphragm caused by TNF- $\alpha$. They found that aerobic exercise promoted antioxidant action, minimizing TNF- $\alpha$ activity and preventing degradation activity through the ubiquitin-proteosome pathway. These findings are plausible for justifying the action of aerobic exercise in attenuating the loss of mass and muscle atrophy in animals with RA and OA.

Also using aerobic exercise, in the study by Assis et al. (Assis et al., 2015), rats were separated into 5 groups: a control group, osteoarthritis group, osteoarthritis group associated with laser, osteoarthritis and aerobic exercise group, and osteoarthritis group with laser associated with aerobic exercise. Three weeks after the induction of OA, running training was started on a treadmill at a speed of $16 \mathrm{~m} / \mathrm{min}$, 50 minutes a day, 3 times a week for 8 weeks. It was observed that in the OA and OA groups with laser associated with aerobic exercise, there was no increase in MuRF-1 enzyme and Atrogin-1 protein expression. A similar study conducted by Martins et al. [29] in an experimental model of knee OA, moderate intensity aerobic training was applied on a treadmill, which started one week after OA induction, at a speed of $16 \mathrm{~m} / \mathrm{min}, 3$ times a week, for 8 weeks and with a time progression from 30 minutes to 50 minutes in the fourth week. After the analysis of joint biomarkers and functional adaptations, aerobic training was found to reduce inflammatory marker levels of inflammatory markers (IL-1 $\beta$, TNF, IL-10 and IL-6) and improve the functional performance of $\mathrm{OA}$ animals.

In turn, in another article included in this review, Oliveira et al. [19] opted for the use of resistance exercise and divided the rats into 4 groups: a control group (no intervention), RA group (induced RA), resistance exercise group (stair climbing with load) and RA group associated with exercise (induced RA and submitted to stair climbing exercise). In the results, the RA group showed increased levels of myostatin in the gastrocnemius muscle, while in the RA group associated with exercise this did not increase, demonstrating that resistance exercise promoted a protective effect in relation to muscle damage. Also using a RA model submitted to the resistance stair climbing exercise, Neves et al. [30] associated exercise with low-intensity LASER treatment. They concluded that the interventions (stair-climbing exercise and LASER), combined or not, caused positive effects on the modulation of the inflammatory process and leukocyte migration, both in the acute or chronic inflammatory process, indicating the benefits of the intervention at the beginning of the disease.

\section{CONCLUSION}

Based on the studies analyzed, it was possible to observe that physical exercise applied in murine models of RA and $\mathrm{OA}$ resulted in benefits to muscle tissue, which suggests an attenuation of the loss of muscle mass that is promoted by these inflammatory pathologies. However, the existence of several modalities and exercise protocols is observed, with varying intensity and parameters. This, added to the scarcity of experimental studies with protocols described in detail, which analyze the loss of muscle mass and the various ways in which exercise can interfere with this aspect, makes the research limited. In view of this, more quality primary studies on the subject are necessary so that future reviews can be more conclusive in answering the real effectiveness of each modality and protocol of exercises on the muscles in models of RA and OA.

\section{REFERENCES}

1. Smolen JS, Aletaha D, Barton A, Burmester GR, Emery P, Firestein GS, et al. Rheumatoid arthritis. Primer. 2018; 4: 01-23. https://doi. org/10.1007/978-3-319-59963-2_3

2. Smolen JS, Aletaha D, McInnes IB. Rheumatoid arthritis. Lancet 2016; 388: 2023-38. https://doi.org/10.1016/S0140-6736(16)30173-8

3. Little RD, Prieto-Potin I, Pérez-Baos S, Villalvilla A, Gratal P, Cicuttini F, et al. Compensatory anabolic signaling in the sarcopenia of experimental chronic arthritis. Sci Rep 2017; 7: 6311. https://doi. org/10.1038/s41598-017-06581-6

4. Casanova-Vallve N, Constantin-Teodosiu D, Filer A, Hardy RS, Greenhaff PL, Chapman V. Skeletal muscle dysregulation in rheumatoid arthritis: Metabolic and molecular markers in a rodent model and patients. PLoS One 2020; 15: e0235702. https://doi.org/10.1371/journal. pone. 0235702

5. Steinz MM, Santos-Alves E, Lanner JT. Skeletal muscle redox signaling in rheumatoid arthritis. Clin Sci 2020; 134: 2835-50. https://doi. org/10.1042/CS20190728

6. Loeser RF, Goldring SR, Scanzello CR, Goldring MB. Osteoarthritis: A disease of the joint as an organ. Arthritis Rheum 2012; 64: 1697-707. https://doi.org/10.1002/art.34453

7. Shorter E, Sannicandro AJ, Poulet B, Goljanek-Whysall K. Skeletal muscle wasting and its relationship with osteoarthritis: a mini-review of mechanisms and current interventions. Curr Rheumatol Rep. 2019; 21: 40. https://doi.org/10.1007/s11926-019-0839-4

8. Santos MLADS, Gomes WF, Queiroz BZ de, Rosa NM de B, Pereira DS, Dias JMD, et al. Desempenho muscular, dor, rigidez e funcionalidade de idosas com osteoartrite de joelho. Acta Ortop Bras 2011; 19: 193-7.

9. Pope JE. Management of fatigue in rheumatoid arthritis. RMD Open 2020; 6: e001084. https://doi.org/10.1136/rmdopen-2019-001084

10. Duarte V de S, Santos ML dos, Rodrigues K de A, Ramires JB, Arêas GPT, Borges GF. Exercícios físicos e osteoartrose: uma revisão sistemática. Fisioter Em Mov 2013; 26: 193-202. https://doi.org/10.1590/S010351502013000100022

11. Rocha TC, Dos Santos Ramos P, Dias AG, Martins EA. The effects of physical exercise on pain management in patients with knee osteoarthritis: A systematic review with metanalysis. Rev Bras Ortop 2020; 55: 509-17. https://doi.org/10.1055/s-0039-1696681

12. Cooney JK, Law R-J, Matschke V, Lemmey AB, Moore JP, Ahmad Y, et al. Benefits of exercise in rheumatoid arthritis. J Aging Res 2011; 2011: 681640. https://doi.org/10.4061/2011/681640

13. Furlanetto Jr R, Souza A de P, Oliveira AA de, Nunes PRP, Michelin MA, Chica JEL, et al. Acute resistance exercise reduces increased 
gene expression in muscle atrophy of ovariectomised arthritic rats Menopausal Rev 2016; 4: 193-201.https://doi.org/10.5114/pm.2016.65663

14. Sharif S, Thomas JM, Donley DA, Gilleland DL, Bonner DE, McCrory $\mathrm{JL}$, et al. Resistance exercise reduces skeletal muscle cachexia and improves muscle function in rheumatoid arthritis. Case Rep Med 2011; 2011: 205691. https://doi.org/10.1155/2011/205691

15. Mikkelsen UR, Dideriksen K, Andersen MB, Boesen A, MalmgaardClausen NM, Sørensen IJ, et al. Preserved skeletal muscle protein anabolic response to acute exercise and protein intake in well-treated rheumatoid arthritis patients. Arthritis Res Ther 2015; 17: 271. https:// doi.org/10.1186/s13075-015-0758-3

16. Fang L, Lin L, Lv Y, Huang Z, Lin X, Wang X, et al. The mechanism of aerobic exercise combined with glucosamine therapy and circUNK in improving knee osteoarthritis in rabbits. Life Sci 2021; 275: 119375. https://doi.org/10.1016/j.lfs.2021.119375

17. Bartels EM, Juhl CB, Christensen R, Hagen KB, Danneskiold-Samsøe B, Dagfinrud H, et al. Aquatic exercise for the treatment of knee and hip osteoarthritis. Cochrane Database Syst Rev 2016; 2016: CD005523. https://doi.org/10.1002/14651858.CD005523.pub3

18. Iversen MD. Rehabilitation interventions for pain and disability in osteoarthritis: A review of interventions including exercise, manual techniques, and assistive devices. Orthop Nurs 2012; 31: 103-8. https:// doi.org/10.1097/NOR.0b013e31824fce07

19. Oliveira AA, Martins FM, Júnior RF, Michelin M, Sousa AP, Nunes PR, et al. Rheumatoid arthritis-increased gene expressions in muscle atrophy are restored back to control as a response to acute resistance exercise. Rev Bras Ciência e Mov 2018; 26: 24-33. https://doi.org/10.18511/rbcm. v26i2.7928

20. Assis L, Almeida T, Milares LP, dos Passos N, Araújo B, Bublitz C, et al. Musculoskeletal atrophy in an experimental model of knee osteoarthritis: The effects of exercise training and low-level laser therapy. Am J Phys Med Rehabil 2015; 94: 609-16. https://doi.org/10.1097/ PHM.0000000000000219

21. Lange E, Kucharski D, Svedlund S, Svensson K, Bertholds G, Gjertsson I, et al. Effects of aerobic and resistance exercise in older adults with rheumatoid arthritis: A randomized controlled trial. Arthritis Care Res (Hoboken) 2019; 71: 61-70. https://doi.org/10.1002/acr.23589
22. Vincent KR, Vincent HK. Concentric and eccentric resistance training comparison on physical function and functional pain outcomes in knee osteoarthritis: A randomized controlled trial. Am J Phys Med Rehabil 2020; 99: 932-40. https://doi.org/10.1097/PHM.0000000000001450

23. Brennan FM, McInnes IB. Evidence that cytokines play a role in rheumatoid arthritis. J Clin Invest 2008; 118: 3537-45. https://doi. org/10.1172/JCI36389

24. Wojdasiewicz P, Poniatowski ŁA, Szukiewicz D. The role of inflammatory and anti-inflammatory cytokines in the pathogenesis of osteoarthritis. Mediators Inflamm 2014; 2014: 561459. https://doi. org/10.1155/2014/561459

25. Wang T, He C. Pro-inflammatory cytokines: The link between obesity and osteoarthritis. Cytokine Growth Factor Rev 2018; 44: 38-50. https:// doi.org/10.1016/j.cytogfr.2018.10.002

26. Adams V, Mangner N, Gasch A, Krohne C, Gielen S, Hirner S, et al. Induction of MuRF1 is essential for TNF- $\alpha$-induced loss of muscle function in mice. J Mol Biol 2008; 384: 48-59. https://doi.org/10.1016/j. jmb.2008.08.087

27. Andonian BJ, Bartlett DB, Huebner JL, Willis L, Hoselton A, Kraus VB, et al. Effect of high-intensity interval training on muscle remodeling in rheumatoid arthritis compared to prediabetes. Arthritis Res Ther 2018; 20: 283. https://doi.org/10.1186/s13075-018-1786-6

28. Mangner N, Linke A, Oberbach A, Kullnick Y, Gielen S, Sandri M, et al. Exercise training prevents TNF- $\alpha$ induced loss of force in the diaphragm of mice. PLoS One 2013; 8: e52274. https://doi.org/10.1371/ journal.pone.0052274

29. Martins JB, Mendonça VA, Aguiar GC, Fonseca SF da, Santos JM dos, Tossige-Gomes R, et al. Effect of a moderate-intensity aerobic training on joint biomarkers and functional adaptations in rats subjected to induced knee osteoarthritis. Front Physiol 2019; 10: 1168. https://doi. org/10.3389/fphys. 2019.01168

30. Neves M, Retameiro ACB, Tavares AL de F, Reginato A, Menolli RA, Leal TS da S, et al. Physical exercise and low-level laser therapy on the nociception and leukocyte migration of Wistar rats submitted to a model of rheumatoid arthritis. Lasers Med Sci 2020; 35: 1277-87. https://doi. org/10.1007/s10103-019-02905-2 